\title{
A DETAILED SURVEY OF JUST-IN-TIME IMPLEMENTATION STATUS WITHIN LIBYAN CEMENT INDUSTRY, AND ITS IMPLICATION FOR OPERATIONS MANAGEMENT
}

\author{
Rajab Abdullah Hokoma \\ Faculty of Engineering, University of Tripoli , Libya \\ E-mail: r.hokoma@uot.edu.ly \\ Hala Mansour Amaigl \\ Ministry of Education and Scientific Research, Libya \\ E-mail: hokoma@hotmail.com \\ Submission: $30 / 09 / 2018$ \\ Revision: 29/10/2018 \\ Accept: 06/11/2018
}

\section{ABSTRACT}

This paper investigates in detail the current status of the implementation levels of JIT key-factors and their sub-elements within the cement industry within Libya, and its implication for management within the said industry. A survey methodology has been applied in this detailed investigation using an intensive questionnaire and one-to-one interviews of the correspondent organizations. Based on the analysis of the survey findings, the results show that the implementation status of the JIT key-factors and their sub-elements are found to be in the modest levels across all the surveyed organisations, thereby indicating to opportunities for eliminating waste and improving the value chain. This paper has also pointed to crucial areas where the senior management body within this industry need to take immediate actions in order to achieve an effective and successful implementation of JIT systems. The paper also makes a contribution by providing an insight into what extent the JIT key-factors and their sub-elements are understood and implemented within the key Libyan manufacturing industry.

Keywords: JIT; Manufacturing; Industry; Questionnaire;

Implementation; Libya 


\section{INTRODUCTION}

Global competition is posing challenges and creating opportunities for manufacturing and business companies to ensure their positions in the marketplace. Improving quality and increasing customers' satisfaction can be effectively used to meet these challenges. Industrial companies as well as academic institutions have paid a considerable attention to JIT, as a new manufacturing approach, developed for increasing the value added on the production processes, and reducing the waste to increase productivity throughout the entire business area (LI-HSING; WEI-FENG, 2013; HOKOMA, 2016a),

Libya was poor before discovering the Oil \& Gas during 1960's. after that, the country paid serious attention towards developing strategies in order to update all areas that could contribute in improving all the industries across the country (RIFAI et. al. 2006; HOKOMA 2016B; HOKOMA et. al. 2008).

However, Libya faced a lot of major problems after the country was embargoed by the UN sanctions during the 1990s. Libya resumed upgrading of its manufacturing industries after the release from these sanctions in 2001, aiming to achieve the most possible benefits by implementing the latest techniques in order to improving the current situation of most industries, including the industry targeted for this study (TUGHAR et. al., 2007).

\section{AN OVERVIEW OF JIT AND ITS KEY-ELEMENTS:}

Most manufacturing companies are trying to implement JIT practices (either partially or fully) in order to achieve continuous improvement in the overall productivity of their products and services. This fact has been well documented in the literature. According to Polat (2005) and Yasutaka (2013), JIT is widely implemented in areas of manufacturing, production and service systems.

This implementation covers all the processes and operations used, including all the elements flowing throughout the entire processes in the whole system and it performed well in reducing the inventory levels. In the same line, Lai et. al. (2003) concluded that JIT could be integrated with supply chain management for product development and inventory reduction in order to reduce the supply chain costs and build good relationships with suppliers. 
INDEPENDENT JOURNAL OF MANAGEMENT \& PRODUCTION (IJM\&P)

http://www.ijmp.jor.br

v. 10, n. 3, May - June 2019

ISSN: 2236-269X

DOI: 10.14807/ijmp.v10i3.882

The literature search has shown that there is a quite large amount of research that has been carried out on JIT and its key-factors, focusing more on their implementation processes along with considering their main objectives Henry (1998), Callen and Itzhak (2000), Dong et. al, (2001), Fullerton and McWatters (2001), Oral and Erdis (2003), Hokoma et. al. (2006) and Hokoma and Amaigl (2016), pointed out that JIT can be implemented to produce goods and services that are needed by customers quickly, safely and economically; to reduce time and cost of material handling by effective arrangement and utilisation of machines; to eliminate all types of waste; to improve the performance of the companies; to minimise the sum of the ordering and set-up times and costs; to compress the leadtime needed for delivering the products and services; to improve customer service level; to increase the competitive edge in the business areas; to reduce the uncertainty in materials demand by linking this with the production plan; to create a stable environment to make JIT work and to reduce costs by using specialised automation machines.

Furthermore, According to Fulletton (2001), the executive management involvement and guidance through all the operations within any company are the main cause of successful implementation of JIT practices. The key elements of JIT and other related issues that are considered as crucial for implementing successful JIT system are; Eliminating Waste, Continuous Improvement Programmes (CIP), Reducing Set-up Time, implementing Preventative Maintenance Programmes (PMP), Kanban, Levelled/Mixed Scheduling Programmes and Teamwork Approach Gargeya (2002),

This paper covers a detailed investigation of the actual implementation status of JIT and its key-factors and their sub-elements within the Libyan Cement industry, thereby, developing their path towards achieving World Class Manufacturing (WCM) status.

\section{METHODOLOGY AND DATA COLLECTION:}

Questionnaire survey was designed to ascertain in detail the current implementation status of JIT key-factors and their sub-elements, which were implemented within the targeted industry. The sub-elements of JIT, being the core of any effective implementation of JIT, were also deeply investigated in order to 
INDEPENDENT JOURNAL OF MANAGEMENT \& PRODUCTION (IJM\&P)

http://www.ijmp.jor.br

v. 10, n. 3, May - June 2019

ISSN: 2236-269X

DOI: 10.14807/ijmp.v10i3.882

ascertain the extent of these implementation levels within the surveyed industry. The targeted people for this survey were the top and senior managers working within the targeted organisations and involved within key decision making processes.

The questionnaire consists of 11 main questions, with the main questions broken down into 99 sub-questions, investigating the extent of use and implementation of each of the investigated JIT key-factors. The respondents were given a choice to indicate their answers to specify the extent use of each of the given approach or technique using Likert Scale from 0 (non-implementation) to 6 (full implementation). The questionnaire was pre-tested through several intensive reviews with academics and experts conversant with the manufacturing areas, and then was passed to expert colleagues for a discussion concerning its contents and the expected level of understanding from the respondents within the targeted industry.

As a first step of distributing the questionnaire, a formal letter was mailed to all the targeted managers, providing a general idea about the survey and its contribution in developing the targeted industry. In the second stage, a total of 800 hard copies of questionnaire were distributed to the targeted managers working within the targeted industry including most of the related managers. Each copy of the questionnaire was accompanied with another letter from the researchers providing the reasons for conducting this survey and providing contact details in a case of any inquiries or clarifications are needed. Out of the 800 questionnaire' copies sent, a total of 520 copies were returned with the full-completed questionnaires, giving a response rate of $65 \%$.

Complementary to the questionnaire survey, couple of interviews were carried out between the researchers and senior managers working within the targeted industry, where information related to the surveyed industry was provided to the interviewers, and site visits to seven correspondent cement factories were additionally carried out in order to collect more knowledge about the manufacturing processes and the working environment within this industry.

\section{DATA ANALYSIS AND DISCUSSION:}

A reliability test was conducted for the entire questionnaire as a first step of analysing the collected data. Cronbach's Alpha was used as the Coefficient of Reliability for testing the internal consistency of the constructs of the entire 
INDEPENDENT JOURNAL OF MANAGEMENT \& PRODUCTION (IJM\&P)

http://www.ijmp.jor.br

v. 10, n. 3, May - June 2019

ISSN: 2236-269X

DOI: 10.14807/ijmp.v10i3.882

questionnaire. The calculated value of Cronbach's Alpha was found to be 0.792 . According to Pallant (2005), a Cronbach's Alpha Coefficient of 0.70 or above is considered adequate for the reliability of the entire questionnaire. Therefore, in this research 0.792 gives strong evidence that the questionnaire responses were reliable.

\subsection{Investigating The Implementation Status of Each JIT Key Factor:}

The survey tried to ascertain the implementation status of the JIT key-factors within the Libyan cement industry in order to provide a detailed picture of the existing JIT environment within this industry. The findings are summarised and illustrated in Table 1. It shows that the implementation status of the first two investigated keyfactors (implementing programmes to eliminate waste and implementing continuous improvement programmes) are affecting the implementation status of the other keyfactors. This is because these two elements are the key-drivers of all the other related JIT key-factors within this industry.

The table shows that the surveyed industry is implementing programmes to eliminate waste with $90 \%$. The continuous improvement programme is found implemented at lower level across the entire industry. These two key-factors should be fully implemented in order to achieve effective implementation of the JIT system, whereas in this survey they are found be practiced at lower implementation levels.

The poorest implementation levels across the entire surveyed industry as expected are with Group Technology, Kanban and implementing Levelled/Mixed Scheduling programmes (all less than 19\%) as these elements are not relevant to this industry (more relevant to batch-size production environments).

These three elements will not be discussed in detail elsewhere. The table also shows that the Preventative Maintenance Programmes are well-implemented throughout the entire industry (above 90\%) as in this industry breakdown affects are critical and need to be avoided. This implementation of PMP programmes requires multifunctional skills employees which also found to be at high levels of implementation.

Worryingly, the Total Quality Management, Quality Circle Programmes and Reducing Set-up Time are implemented at modest levels, where more attention should be paid in order to achieve effective and successful implementation of JIT 
INDEPENDENT JOURNAL OF MANAGEMENT \& PRODUCTION (IJM\&P)

http://www.ijmp.jor.br

v. 10, n. 3, May - June 2019

ISSN: 2236-269X

DOI: 10.14807/ijmp.v10i3.882

system within the cement industry. In particular, the overall implementation status of JIT key-factors within the cement industry is modest across all the investigated categories. This situation needs immediate and serious actions in order to achieve the desired benefits of implementing JIT system.

Table 1: The implementation status of the JIT key-factors

\begin{tabular}{|l|c|c|c|}
\hline \multirow{2}{*}{ JIT Key-factor } & \multicolumn{3}{c|}{ Implementation level (\%) } \\
\cline { 2 - 4 } & Yes & No & Do Not Know \\
\hline Implemented programmes to eliminate waste & 90.0 & 10.0 & 00.0 \\
\hline Implemented programmes for continuous improvement & 72.7 & 18.2 & 09.1 \\
\hline Implementing programmes to reduce set-up times & 45.5 & 45.4 & 09.1 \\
\hline Implemented programmes for Group Technology layout & 09.1 & 54.5 & 36.4 \\
\hline Implemented levelled/mixed scheduling programmes & 09.1 & 54.5 & 36.4 \\
\hline Used Kanban cards/signals as a production control system & 18.2 & 54.5 & 27.3 \\
\hline Implemented a multifunctional skills training programme & 72.7 & 00.0 & 27.3 \\
\hline Implemented preventative maintenance programmes & 91.0 & 00.0 & 09.0 \\
\hline Implemented Total Quality Management programmes & 63.6 & 18.2 & 18.2 \\
\hline Implemented Quality Circle programmes & 54.5 & 09.1 & 36.4 \\
\hline
\end{tabular}

\subsection{Investigating The Extent of Each JIT Key-Factor Implementation Levels:}

The implementation status of the JIT key-factors was investigated in detail, broken down into sub-elements for each of the main questions in order to ascertain the actual implementation status of each of these key-elements within the surveyed industry. The calculated mean values of all these sub-elements of the JIT key-factors are shown in Tables 2 to 8 . The key-factor of eliminating the waste is broken down into 8 sub-elements, which are illustrated along with their implementation status in Table 2 on a scale of 0 (non-implementation) to 6 (full implementation).

Table 2: The implementation status of eliminating the waste

\begin{tabular}{|l|c|}
\hline Implementing programmes to eliminate the waste & Mean value \\
\hline Eliminated the waste due to over production & 3.82 \\
\hline Eliminated the waste by reducing the queues and the waiting times & 2.82 \\
\hline Planned and controlled the operations avoiding any extra operations & 3.09 \\
\hline Eliminated the waste due to delay of materials before processing & 3.18 \\
\hline Eliminated the waste due to unnecessary transportation of materials & 3.36 \\
\hline Eliminated the waste by reducing the inventory materials & 3.09 \\
\hline Eliminated the waste by producing ZERO defects & 3.09 \\
\hline Eliminated the waste due to proper utilisation of the employees & $\underline{4.00}$ \\
\hline Overall mean value & $\mathbf{3 . 3 1}$ \\
\hline
\end{tabular}

Looking at Table 2, the cement industry is with modest level of implementation of waste elimination programmes with overall mean values of 3.31 . This indicates to a lot of potential to reduce costs and make the operations more efficient within each 
INDEPENDENT JOURNAL OF MANAGEMENT \& PRODUCTION (IJM\&P)

http://www.ijmp.jor.br

v. 10, n. 3, May - June 2019

ISSN: 2236-269X

DOI: 10.14807/ijmp.v10i3.882

of these sub-elements. This also shows room for improvement. However, even this indicates to potential cost saving. Table 3 shows the implementation of sub-elements of continuous improvement. This also worryingly a very poor implementation as the overall mean values across the entire industry is 2.85 over 6 . On closer inspection on Table 3 , the first five listed sub-elements of continuous improvement show why this is the case.

These five sub-elements show top management commitment towards implementing the remaining sub-elements. As can be seen these are mainly below 3 , which is very poor. This then is reflected in the poor implementation in the various functional areas of the surveyed industry. The programmes implemented to reduce the set-up times have been investigated in order to assess the extent of this implementation within the surveyed industry.

Table 3: The implementation status of the continuous improvement programmes

\begin{tabular}{|l|c|}
\hline Implementing programmes for Continuous Improvement Programmes (CIP) & Mean Value \\
\hline The top management responded to the feedback from the employees on JIT/ CIP & 1.73 \\
\hline Ensuring training programmes for the management body on JIT/ CIP & 1.45 \\
\hline Ensuring training programmes to the administrative staff on JIT/ CIP & 2.91 \\
\hline $\begin{array}{l}\text { The training programmes designed considering the variety of the employees' } \\
\text { learning needs }\end{array}$ & 2.82 \\
\hline Ensuring Continuous Improvement training programming to the machine operators & 2.45 \\
\hline Carrying out research and development to improve the products & 3.00 \\
\hline Encouraging a continuous improvement culture within the working environment & 2.73 \\
\hline Focusing on the requirements of their customers in designing products & 2.73 \\
\hline Using team-based approaches to problem solving & 3.18 \\
\hline The CIP been implemented in the Marketing function & 2.82 \\
\hline The CIP been implemented in the Design function & 3.45 \\
\hline The CIP been implemented in the Production/Manufacturing function & 3.45 \\
\hline The CIP been implemented in the Purchasing function & 3.55 \\
\hline The CIP been implemented in the Finance function & 3.45 \\
\hline The CIP been implemented in the Production Shop Floor function & 2.36 \\
\hline The CIP been implemented in the Materials Handling Control function & 3.09 \\
\hline The CIP been implemented in the Quality Control function & 4.00 \\
\hline The CIP been implemented in the Preventative Maintenance function & 3.82 \\
\hline The CIP been implemented in the shipping function & 3.18 \\
\hline Overall mean value & 2.85 \\
\hline
\end{tabular}

The results are summarised in Table 4. It shows the sub-elements of set-up time reduction programmes with an overall mean value of 2.44. Again this table highlights the shortcomings of the first two sub-elements, which are then effecting the subsequent implementation of the other sub-elements. A case in point is the low 
INDEPENDENT JOURNAL OF MANAGEMENT \& PRODUCTION (IJM\&P)

http://www.ijmp.jor.br

v. 10, n. 3, May - June 2019

ISSN: 2236-269X

DOI: 10.14807/ijmp.v10i3.882

values for implementing internal and external activities reduction, which indicate to complete lack of knowledge of this implementation task, no doubt due to the shortcomings identified for the first two sub-elements in Table 4.

The extent of the implementation levels of the multi-skilled training programmes is also investigated and the findings are summarised in Table 5. The table shows that the overall mean values for the multi-skilled training programmes are relatively higher than the values in the previous tables. This is a slightly encouraging picture for the cement industry. However, there is room for improvement, and needs to drastically address the issue of training staff.

Table 4: The implementation status of reducing the set-up times programmes

\begin{tabular}{|c|c|}
\hline Implementing any programmes to reduce set-up times & Mean Value \\
\hline All the employees trained for set-up time reduction process & 2.36 \\
\hline The employees trained to perform the set-up of their machines on time & 2.45 \\
\hline The operators trained for mounting and handling items and materials & 2.81 \\
\hline The operators trained to use the set-up tools & 2.82 \\
\hline The operators trained to understand and use the set-up drawings & 2.64 \\
\hline The operators have sufficient knowledge about their machines set-ups & 2.82 \\
\hline The operators have enough skills in improving set-up times & 2.73 \\
\hline The set-up time reduction programmes involving a multifunctional team approach & 2.73 \\
\hline The relevant teams aware of clear definition of the set-up times & 2.73 \\
\hline The relevant teams aware of the distinction between internal and external set-up activities & 2.64 \\
\hline $\begin{array}{l}\text { The teams converted the internal activities to external ones by re-examining their true } \\
\text { functions }\end{array}$ & 2.09 \\
\hline The teams changed as many internal activities to external activities as possible & 2.36 \\
\hline The teams actually performed the external activities as external activities & 1.73 \\
\hline The teams videotape the changeover and review for opportunities for improvements & 1.64 \\
\hline $\begin{array}{l}\text { The teams reduce the time needed to perform internal activities by using quick } \\
\text { disconnects }\end{array}$ & 2.05 \\
\hline Overall mean value & 2.44 \\
\hline
\end{tabular}

Table 6 illustrates the implementation status of the Preventative Maintenance Programmes, which found to be stands at High levels with overall mean value of 3.95. As mentioned earlier, within this industry any breakdown is critical and thus there is a lot of investment of resources for preventative maintenance to ensure that no such breakdowns occur, and leaving much room for improvements in cost savings. 
INDEPENDENT JOURNAL OF MANAGEMENT \& PRODUCTION (IJM\&P)

http://www.ijmp.jor.br

v. 10, n. 3, May - June 2019

ISSN: 2236-269X

DOI: 10.14807/ijmp.v10i3.882

Table 5: The implementation status of the multifunctional skills training programmes Implementing a multifunctional skills training programme

The employees receive cross-training programmes Mean Value

The employees qualified to perform several different tasks 3.64

The employees qualified to train and/or be trained for their duties 3.45

The employees able to rework the non-conforming items by their own 3.36

The employees inspect the produced items

3.45

The employees maintain the inventory and production control 3.64

The employees qualified to set-up their equipment and tools 4.45

The employees able to execute the minor maintenance needed

4.18

Overall mean value

$\underline{4.64}$

3.74

Tables 7 and 8 , show the detailed investigation results of the implementation status of quality management programmes within the surveyed industry. The results within Tables 7 and 8 show an extremely worrying picture in that the overall mean values range from 1.38 (TQM programmes) and to 2.89 for Quality Circle (QC) programmes. The sub-elements contained within both tables reflect the overall mean values.

Table 6: The implementation levels of the preventative maintenance programmes

\begin{tabular}{|c|c|}
\hline Implementing preventative maintenance programmes & Mean Value \\
\hline The factory has any preventative maintenance system & 4.00 \\
\hline The factory keeps records of preventative maintenance schedules & 4.18 \\
\hline The factory schedules the planned preventative maintenance & 4.00 \\
\hline $\begin{array}{l}\text { The preventative maintenance activities scheduled with the main production } \\
\text { programme }\end{array}$ & 4.19 \\
\hline The managers track preventative maintenance programmes & 4.27 \\
\hline The maintenance department take the needed actions on time & 4.00 \\
\hline The factory keeps records of individuals performing major overhauls & 3.91 \\
\hline The operators trained by preventative maintenance people & 3.09 \\
\hline The factory keeps records of breakdown frequencies & 4.00 \\
\hline The factory keeps records of the repair times & 3.91 \\
\hline Overall mean value & 3.95 \\
\hline
\end{tabular}

Table 7: The implementation level of the TQM programmes

\begin{tabular}{|l|c|}
\hline The factory implemented Total Quality Management programmes & Mean Value \\
\hline Implemented any of ISO9000 systems or equivalent & $\underline{3.45}$ \\
\hline Implemented Statistical Process Control (SPC) & 1.18 \\
\hline Implemented Quality Function Deployment (QFD) & 0.91 \\
\hline Implemented Failure Mode and Effect Analysis (FMEA) & 0.55 \\
\hline Implemented Experimentation (Taguchi) methods & 0.55 \\
\hline Overall mean value & $\mathbf{1 . 3 8}$ \\
\hline
\end{tabular}


INDEPENDENT JOURNAL OF MANAGEMENT \& PRODUCTION (IJM\&P)

http://www.ijmp.jor.br

v. 10, n. 3, May - June 2019

ISSN: 2236-269X

DOI: 10.14807/ijmp.v10i3.882

Table 8: the extent of the implementation status of the QC programmes

\begin{tabular}{|c|c|}
\hline The factory implemented any Quality Circle programmes & Mean Value \\
\hline The employees have the authority to stop the production line due to QC problems & 2.73 \\
\hline The employees been organised into self-directed teams & 2.82 \\
\hline The employees been able to identify their operations problems & $\underline{3.18}$ \\
\hline The employees suggested improvement programmes & 3.00 \\
\hline The employees participated in decision-making process & 2.91 \\
\hline The employees met to discuss their common problems & 2.73 \\
\hline Overall mean value & 2.89 \\
\hline
\end{tabular}

In summary, it seems that the surveyed industry is not what one could call TQM-centred. This is also the reason why this industry has not achieved successful JIT implementation, as both JIT and TQM are closely linked.

\section{CONCLUSIONS:}

This is the first study to investigate the detailed actual implementation status of the JIT and its key-factors and their sub-elements within the cement industry in Libya. It makes a contribution by providing an insight into what extent these keyfactors are being practiced along with their implication for the manufacturing and quality operations within this industry. Some key findings can be summarised as follows:

- The actual implementation status of JIT practices across the entire surveyed industry is modest because of unfamiliarity with JIT and some of its key-factors and lack of support from the executive managers towards this implementation process. The executive managers within this industry should take serious actions through applying a clear strategy towards most of the areas that are considered as being crucial in any effective implementation of the JIT system.

- The actual implementation status of eliminating the waste and implementing programmes for continuous improvement programmes (as the most crucial JIT key-factors) is found to be modest throughout the entire surveyed industry. In order to achieve effective implementation of the JIT system, these two key-factors should be fully implemented across the entire surveyed industry. The key reason for this modest implementation is 
lack of support from the senior managers towards this implementation. Again, action is required by senior managers to overcome these hurdles.

- Some of the investigated JIT key-factors were found to be implemented at very poor levels, the reason being that these key-factors are not related to this industry and are more related to batch-size production industries.

- The vision of improving the Libyan cement industry with respect to JIT could be achieved through setting up employers' training and on-going education programmes for all the related individuals and teams in order to make it easier for local employers and employees.

- The survey has also identified difficulties and attitudes that the decisionmakers within industry in general might face towards implementing the JIT system along with the subsequent key-factors. Therefore, ensuring a high level of understanding of the whole JIT manufacturing system to all the involved teams and individuals certainly will lead to an effective implementation of JIT as manufacturing management system, thereby moving the Libyan industries towards WCM.

To summarise, this survey has identified problems faced by the Libyan cement industry. The findings of this survey have provided insight into the common problems and shortcomings related to JIT implementation in the surveyed industry. If JIT implementation is critical to achieve WCM status, then the findings of this survey can help others considering a conversion to a JIT system improve the likelihood of a successful JIT implementation.

The surveyed industry is crucial for Libyan economy. However, this survey has identified that it needs more attention in terms of JIT implementation and therefore WCM. In essence, the key reason for this modest status is the lack of the senior managers' support towards the implementation process through providing a high level of awareness about the issue to all the related individuals and teams.

Finally, on a positive note, when asked (during one-to-one interviews) about improving the Libyan cement industry, all the respondents (without any exception) showed serious willingness and enthusiasm on developing their business areas 
INDEPENDENT JOURNAL OF MANAGEMENT \& PRODUCTION (IJM\&P)

http://www.ijmp.jor.br

v. 10, n. 3, May - June 2019

ISSN: 2236-269X

DOI: 10.14807/ijmp.v10i3.882

through implementing the latest manufacturing management systems in order to achieving a high level of improvements.

\section{ACKNOWLEDGMENT:}

This research is fully supported by the Authority of Natural Science Research and Technology, Ministry of Education, Tripoli, Libya, with the research project entitled: Developing JIT/TQM Model For Its Possible Effective Implementation Within The Libyan Cement Industry. The authors are grateful to whom they participated and supported this survey.

\section{REFERENCES:}

CALLEN, L.; ITZHAK, K. (2000) Just-In-Time: A Cross-Sectional Plant Analysis. International Journal of Production Economics, v. 63.

DONG, Y.; CARING; DRESNER, E. (2001) JIT Purchasing and Performance: An Exploratory Analysis Of Buyer And Supplier Perspectives. Journal of Operations Management, v. 19, p. 471-483.

FULLERTON, R.; MCWATTERS, (2001) The Production Performance Benefits From JIT Implementation. Journal of Operations Management, v. 19.

GARGEYA, T. (2002) Impact of JIT on Inventory to Sales Ratio, Journal of Industrial Management and Data Systems, v. 102, n. 4.

HENRY, C. (1998) The Human Factor in Advanced Manufacturing Technology Adoption, International Journal of Operations \& Production Management, v. 18, n. 1.

HOKOMA, R.; AMAIGL, H. (2016) Manufacturing Resources Planning In Action: The Case of Cement Industry, proceedings of the sixth international conference on industrial engineering and operations management, (IEOM2016), Malaysia.

HOKOMA, R. (2016) A Survey Investigation of Just-In-Time Implementation and Its Implications for Management in Four key Industries within Libya, International Journal of Engineering Research \& Technology, v. 5, n. 12.

HOKOMA, R. (2016) A Way Forward For Implementing Just-In-Time Techniques Within Oil \& Gas Industries: Domestic Appliances, Journal of Engineering Research, Faculty of Engineering, University of Tripoli, n. 21, Tripoli, Libya.

HOKOMA, R.; BINDRA, S.; ESBAIGA, M. (2008) Textile Industry in North Africa Region: A Case of Total Quality Management (TQM) Within The Libyan Textile Industry, Proceeding of the quality conference 2008, Tripoli, Libya

HOKOMA, R.; KHAN, K.; HUSSAIN, K. (2006) The Current Status of MRPII Implementation in Some Key Manufacturing Industries within Libya: A Survey Investigation, Proceedings of the $22^{\text {nd }}$ international conference, Narosa Publishing House, New Delhi.

LAI, C.; LEE, W.; IP, W. H. (2003) A Study of System Dynamics in Just-in-Time Logistics, Journal of Materials Processing Technology, v. 138, n. 1. 
LI-HSING; WEI-FENG; (2013) Applying a Just-In-Time Integrated Supply Chain Model With Inventory and Waste Reduction Considerations, American Journal of Applied Sciences, v. 10, n. 7, p. 751-759.

ORAL, E.; ERDIS, E. (2003) JIT in Developing Countries-a Case Study of the Turkish Prefabrication Sector, Building and Environment, v. 38, n. 6.

PALLANT, J. (2005) SPSS Survival Manual. UK: McGraw-Hill Education, Open University Press.

POLAT, A. (2005) The JIT Materials Management System in Developing Countries, Construction Management and Economics, v. 23, p. 697-712.

RIFAI, A.; HOKOMA, R.; ESBAIGA, M.; AMAIGL, H. (2006) The Strategy Applied Towards Implementing JIT and MRPII Planning and Control Techniques within Libyan Construction and Cement Industries, Proceedings of the international conference on technology management, Kuala Lumpur, Malaysia.

TUGHAR, M.; RIFAl, A.; EDAAYF, R.; HOKOMA, R. (2007) Management of Energy and Water Saving For Concrete Structures in Coastal States, Proceeding of first international conference and exhibition on environmental impact of energy and water saving in tourism industry, International Energy Foundation, Tripoli, Libya.

YASUTAKA, (2013) A Large-Scale Empirical Study of Just-in-Time Quality Assurance, IEEE Transactions on Software Engineering, v. 39, n. 6. p. 757-773. 